\title{
Antigravity craft slips past patent officers
}

The US patent office has granted a patent on a design for an antigravity device - breaking its own resolution to reject inventions that clearly defy the laws of physics.

This is not the first such patent to be granted, but it shows that patent examiners are being duped by false science, says physicist Robert Park, watchdog of junk science at the American Physical Society in Washington DC. Park tracks US patents on impossible inventions. "The patent office is in deep trouble," he says.

"If something doesn't work, it is rejected," insists Alan Cohan, an adviser at the patent office's Inventors Assistance Center in Alexandria, Virginia. And when something does slip through, he says, the consequences are not significant: "It doesn't cause any problems because the patent is useless."

But Park argues that patenting devices that so blatantly go against scientific understanding could give them undeserved respectability, and undermine the patent office's reputation. "When a patent is awarded for an idea that doesn't work, the door is opened for sham."

Patent $6,960,975$ was granted on 1 November to Boris Volfson of Huntington, Indiana. It describes a space vehicle propelled by a superconducting shield, which alters the curvature of space-time outside the craft in a way that counteracts gravity. The device builds on a claim by the Russian physicist Eugene

\section{IMAGE UNAVAILABLE FOR COPYRIGHT REASONS}

Balls up: US patent office falls for antigravity device that would allow perpetuar-motion machines.

Podkletnov that superconductors can shield the effects of gravity. NASA was at one stage investigating the idea, but it has become almost as notorious as cold fusion as an example of fringe science.
One of the main theoretical arguments against antigravity is that it implies the availability of unlimited energy. "If you design an antigravity machine, you've got a perpetualmotion machine," says Park. Shield half of a wheel from gravity and it will keep turning for ever.

The US patent office has long fought to prevent applications for patents on perpetualmotion machines. In 1911, after a constant stream of applications, one commissioner ruled that they would not be considered until a working model had been running for a year. More recently, inventor Joe Newman sued the office after it rejected his application for such a device. The court finally ruled against Newman in 1990, a decision that the patent office cites in its rules about which inventions are patentable.

Unfortunately, it is not always easy to tell what the implications of a patent are. One previous patent for a device using putative "hydrinos ${ }^{\text {s }}$ - shrunken hydrogen atoms - to produce huge amounts of energy was granted. It is currently being reviewed after several scientists complained that hydrinos are impossible according to the laws of physics.

Park says he sympathizes with the difficulties that patent examiners face. ${ }^{\alpha}$ Their burden has gone up enormously, he says. "It's not surprising they get in a jam."

Philip Ball

\section{Bush buries US bunker-buster project}

\section{WASHINGTON DC}

Bowing to congressional pressure, the administration of President programme to design a nuclear warhead capable of striking targets buried deep in the ground. It has instead chosen to develop replacement warheads for the existing nuclear stockpile.

The cancelled weapon, called the Robust Nuclear Earth Penetrator (RNEP), was proposed three years ago (see Nature 415 , toughened version of an exis ting warhead that could strike bunkers and other underground targets.

However, some physicists were sceptical that the warhead, known George W. Bush has killed a 945; 2002). It was to have beena as the 'bunker-buster', could penetrate deeply enough to contain its massive nuclear blast. A National ResearchCouncil study released in May showed that the weapon would be highly effective at destroying deeply buried targets. But casualties could still number in the thousands, says John Ahearne of the scientific research society Sigma Xi, whochaired the study.

Within Congress, Republicans and Democrats alike opposed RNEP development on both political and technical grounds. Last year, a bipartisan coalition killed funding for the programme. In the face of such opposition, the administration has essentially pulled the plug on the project by withdrawing the $\$ 4$ million requested to study RNEP, according toSenator Pete Domenici (Republican, New Mexico).

"The focus will now be with the defense department and its research into earth-penetrating technology using conventional weaponry," Domenicisaid in a statement.

"This decision simply confirms what the critics have been saying all along," says Christopher Paine, a senior analyst at the Natural Resources Defense Council. "The programme had become a thorn in the side of the administration."

But as RNEP disappears, another project is on the rise.
A congressional budget bill expected out this week would allocate $\$ 25$ million to speed up the Reliable Replacement Warhead project. The programme, established to design the next generation of weapons for the ageing nuclear stockpile, has itself been generating controversy among researchers, some of whom believe it to be unnecessary (see Nature 434, 684; 2005).

"RNEP may be politically dead," says Daryl Kimball, executive director of the Arms Control Association in Washington DC. "But I would be very sur prised if the debate overnew weapons ends any time soon." Geoff Brumfiel \section{(2)}

